\title{
SOCIAL ASSISTANCE IN THE HISTORY OF THE BLACK SEA PEOPLES
}

\author{
(C) Evgeny P. Agapov, Lyudmila P. Pendyurina \\ Rostov State University of Economics, Don State Technical University, \\ Rostov-on-Don, Russian Federation \\ march10@mail.ru, prinpet@mail.ru
}

The article considers the influence of ancient Greek charity on the social assistance of the Black Sea region peoples. Social work became a profession only at the beginning of the last century, but its roots go back to antiquity, when forms of social assistance began to develop among various peoples. It was then that a social assistance mechanism developed, which boiled down to the fact that the family, community and other traditional structures protected everyone. This mechanism of social assistance was characteristic of Tauris, Scythians, Sarmatians and other Black Sea peoples. The same relations were characteristic for Ancient Greece as well as for other states of the Middle East region until the era of antiquity, the beginning of which dates back to the second third of the 1st millennium BC. These relations was marked by the dominance of community ties and the inherited Basileus power as well as the underdevelopment of private property. However, in the 8th century BC in Ancient Greece, structural transformations began, private property relations, the dominance of private commodity production, the exploitation of slaves, the absence of strong centralized power and the policy of selfgovernment came to the fore. With the transformation of the state into an instrument of domination of private owners, social assistance was of a class nature, which manifested itself in the fact that slaves were actually deprived of it. On the other hand, charity, which manifested itself in the organization of public meals, the distribution of money to the needy, the construction of churches and baths through private donations, and other events, became an integral element of the antiquity's public life. According to the authors, we can talk about two channels of influence of ancient Greek charity on the social assistance of the Black Sea peoples. The first of these channels called direct is associated with the creation of Greek colonies along the Black Sea coast. The second channel can be called indirect, since it was mediated by the culture of Ancient Rome. At the beginning of the 1st millennium in ancient Roman society, a contradiction arose between the need for social assistance and the limited possibilities for its implementation, which was removed by Christianity. According to Christianity, mercy follows from love, which coincides with the essence of God and charity is a practical expression of mercy. Therefore, the spread of Christianity that began in the Black Sea countries in the 4th century contributed to the development of charitable activities in them.

Key words: social work, social assistance, family, community, hospitality, beggars, petition, charity, philanthropy.

\section{[Е.П. Агапов, Л.П. Пендюрина Социальная помощь в истории народов Причерноморья]}

Рассматривается влияние древнегреческой благотворительности на социальную помощь народов Причерноморья. Социальная работа стала профессией только в начале прошлого столетия, однако её корни уходят во времена древности. Именно тогда сложился механизм социальной помощи, который сводился к тому, что каждый человек находится под защитой семьи, общины и других традиционных структур. Этот механизм социальной помощи был характерен для тавров, скифов, сарматов и других причерноморских народов. До эпохи античности, начало которой относится ко второй трети первого тысячелетия до н. э., для Древней Греции были характерны те же отношения, что и для других государств ближневосточного региона. Эти отношения характеризовались господством общинных связей и передававшейся по наследству властью басилевсов, а также неразвитостью частной собственности. Однако в VIII в. до н. э. в Древней Греции начались структурные преобразования, которые привели к выходу на первый план частнособственнических отношений, господству частного товарного производства, эксплуатации рабов, отсутствию сильной централизованной власти и полисному самоуправлению. С превращением государства в инструмент господства частных собственников социальная помощь приобрела классовый характер, который проявлялся в том, что рабы были фактически лишены её. С другой стороны, неотъемлемым элементом общественной жизни античности стала благотворительность, которая проявлялась в организации общественных трапез, раздаче денег нуждающимся, строительстве храмов и бань за счёт частных пожертвований, а также других мероприятиях. По мнению авторов, можно говорить о двух каналах влияния древнегреческой благотворительности на социальную помощь народов Причер- 
номорья. Первый из этих каналов, называемый ими прямым, связан с созданием греческих колоний по всему побережью Чёрного моря. Второй канал может быть назван косвенным, поскольку он был опосредован культурой Древнего Рима. В начале первого тысячелетия в древнеримском обществе возникло противоречие между потребностью в социальной помощи и ограниченными возможностями её реализации, которое было снято в христианстве. Согласно христианству, милосердие вытекает из любви, совпадающей с сущностью Бога, а практическим выражением милосердия оказывается благотворительность. Поэтому распространение христианства, начавшееся в странах Причерноморья в IV в., способствовало развитию в них благотворительной деятельности.

Ключевые слова: социальная работа, социальная помощь, семья, община, гостеприимство, нищие, просительство, благотворительность, филантропия.

Evgeny P. Agapov - Ph.D. (Advanced Doctorate) in Philosophy, Professor, Rostov State University of Economics, Rostov-on-Don, Russian Federation.

Lyudmila P. Pendyurina - Ph.D. (Advanced Doctorate) in Philosophy, Associate Professor, Don State Technical University, Rostov-on-Don, Russian Federation.

Агапов Евгений Петрович - доктор фрилософрских наук, профрессор, Ростовский государственный экономический университет, г. Ростов-на-Дону, Российская Федерация.

Пендюрина Людмила Петровна - доктор фрилософских наук, доцент, Донской государственный технический университет, г. Ростов-на-Дону, Российская Федерация.

An integral element of modern culture is social work, which is understood as professional assistance to people who find themselves in difficult situations. It acquired the status of a profession only at the beginning of the last century, however, its roots go back to antiquity, when various peoples appeared and began to develop forms of social assistance that formed the basis of their existence. It was then that this mechanism developed, which boiled down to the fact that each person was protected by traditional structures, which included primarily the family and the community. This mechanism of social assistance was characteristic of the Thracians, Tauris, Cimmerians, Scythians, Sarmatians, and other Black Sea peoples. However, the ancient Greeks appeared in the Black Sea region in the middle of the 8th century $\mathrm{BC}$ and they were far exceed that of other peoples there not only in economic and political, but also in social development. The forms of social assistance they created influenced other nations becoming the property of world culture. Therefore, we can assume that in antiquity the social assistance of the peoples of the Black Sea region experienced Greek influence. But how strong was this influence and which nations experienced it to a greater extent, and which to a lesser one?

The authors are aware that due to the complexity of the subject, which is several thousand years distant from us, it is rather difficult to give detailed answers to the questions they formulated. Therefore, they see their task in focusing on these issues, which are practically not discussed in the literature of the history of culture, as well as outlining the most common ways of their possible solution. To achieve their goals, they use the method of analysis of documents, as well as methods of deduction and analogy.

Ancient Greek tribes appeared in the south of the Balkan Peninsula, as well as the adjoining islands of the Aegean Sea at the end of the 2nd millennium BC. Coming from Eastern Europe, they created their own culture, based on the achievements of the peoples assimilated by them. In the 8-6 centuries BC in ancient Greece, there was a polis system that determined its development until the era of Alexander the Great, which put an end to independent city-states. However, before the era of antiquity, the beginning of which is attributed to the second third of the 1st millennium BC, Ancient Greece had approximately the same relations as other states of the Middle East region. They were characterized by the dominance of community ties and the inherited power of the Basileus, as well as the underdevelopment of private property relations, a poetic description of which we find in Homer $[4,16]$. 
The traditional institutions of social assistance at the time of Homer were the family and the community, which included phratries and phyles. The phyle consisted of several phratries, which in turn represented an alliance of several clans. However, there were other institutions that were a specific manifestation of social assistance during the time of Homer. These include the institution of hospitality, the institution of beggars and the institution of petition [8, p. 33].

Hospitality is a social phenomenon whose foundations began to emerge in a primitive society. In the conditions of inter-tribal conflicts, when members of different tribes shared hunting and collective lands, it was necessary in order to ensure mutual security. Many ancient peoples were characterized by providing any guest with shelter and food, caring for him, fulfilling all his requests, as well as revenge for damage to his person and property [5, $\mathrm{p}$. 148]. In the works of Charles Letourneau, Ferdinand Tönnies and other sociologists who studied the life of primitive and traditional societies, there were references to hospitality. They can be also found in the works of travelers describing the rituals and life of primitive peoples. American anthropologist George Murdock attributed hospitality to cultural universals that are inherent in all cultures, regardless of their geographical, historical and social differences [6, $p$. 128]. Since foreigners were disenfranchised in antiquity, hospitality served as a form of protection for their identity and property. The ancient Greeks believed that the guest was under the protection of Zeus and other gods. Hospitality was known in the days of Homer, and under the policy of democracy, the institution of proxeny was formed, which had the significance of a kind of diplomatic representation. The ancient Greeks were in great demand as a proxenos (gr. Guest friend), which was performed by a citizen of the polis, representing the interests of another policy in his homeland [8, p. 464].

The institution of beggars in Ancient Greece had both an economic and a legitimate basis. Feeding system of community beggars was based on the redistribution in their favor of agricultural products created by different layers of the polis. Participation in the holidays, as well as in individual and collective sacrifices, allowed the community beggars not only to survive, but also to be able to live in dignity. Poverty brought a person to the lowest level of society, making him defenseless. It caused the contempt of the world around them devoid of sympathy. At the same time, poverty was not considered a hallmark of moral inferiority, and traits of corruption and depravity were often associated with wealth.

The institution of petition, originating in a tribal society, has an ancient tradition. It was known to all the peoples of the world, and among the ancient Greeks it was called hikesia. Petition is possible only when there is an institution that has material resources and is able to satisfy the needs of the petitioners. Therefore T. Zieliński, who is considered one of the leading experts in the field of ancient culture, considered petition and hospitality two sister institutions, united by the common patronage of Zeus [9, p. 36].

As the institutions of social assistance mentioned above are universal, it we can assume that in the days of Homer they existed not only among the ancient Greeks, but also among other peoples of the Black Sea region. However, structural transformations began in the 8th century in Ancient Greece, which had a huge impact on the subsequent development of culture. The development of trade relations and Mediterranean navigation, coupled with favorable geographical conditions, played a role in the archaic revolution, which led to the transformation of the pre-antique structure into the ancient one. This transformation was reduced primarily to the fact that private property relations came to the fore, along with the dominance of private commodity production, the exploitation of slaves, the absence of a strong centralized power and polis self-government. After the reforms carried out by Solon, it was completed in the 6th century BC [4, p. 16-17].

Antiquity made human freedom the highest value, the basis of which was private property. At the same time, bringing of private property to the forefront destroyed the traditional mechanism of social assistance, which was guarded by the state. With the transformation of 
the state into an instrument of domination by private owners, social assistance acquired a class nature, which manifested itself in the fact that slaves were actually deprived of it. On the other hand, charity, which was designated by the word "philanthropy", became an integral element of public life from antiquity.

The word "philanthropy" in the ancient Greek language appeared due to the outstanding tragedian Aeschylus who lived in 6-5 centuries BC. In the tragedy "Prometheus Chained," he used that word to indicate the love for people that Prometheus demonstrated. Prometheus taught people to use fire, as well as engage in arts and crafts contrary to the prohibition of Zeus. He in response sentenced the Titan to eternal torment, and the most skillful blacksmith Hephaestus criticized his friend for his excessive love for people [2, p. 80].

The word "philanthropy" initially meant divine help to people then later any help to people. In other words, it has become regarded as a synonym for charity. For over a century of existence as a profession, social work has developed a categorical apparatus that includes concepts that came into it from other areas of knowledge, as well as its specific concepts. The central position in the categorical apparatus of social work is occupied by the concept of charity, which means gratuitous help to those in need, the motives of which can be both religious and secular. At present, it is no longer identified with the concept of philanthropy, but its roots go back to antiquity, when the Greeks began to speak not about community help for those in need, but about humanity.

Ancient Greek charity, which was organized by one of the members of the city council, existed in various forms. It included the organization of public meals in which all citizens of the polis could take part, the distribution of money to the needy, the construction of churches and baths at the expense of private donations, as well as other events. At the same time, charity among the ancient Greeks did not extend to slaves, whom they considered not people, but the same tools as animals. In addition, some traditions prevailing in ancient Greece were far from humanity. So, many polises specifically contained cripples and idiots, as well as those sentenced to death, so that in the case of a famine or epidemic of the plague, they could be sacrificed to the gods [3, p. 25]. However, even with the limited nature of charity, as well as the existence of inhuman traditions, the merits of the ancient Greeks in the development of social assistance cannot be downplayed. The word "philanthropy" entered many languages, and the forms of social assistance that arose in antiquity became the property of world culture.

We believe that we can talk about two channels of the influence of ancient Greek charity on the social assistance of the Black Sea peoples. The first of these canals, which can be called direct, is associated with the creation of Greek colonies along the Black Sea coast. Despite the fact that the colonization process, which began in the 8th century, took place spontaneously, it was completed in two centuries. Its causes were both economic and political in nature. The economic causes of Greek colonization includeв overpopulation, low agricultural productivity, as well as an increase in the landed estates of the nobility due to small farmers. As for political reasons, they were associated with the intensification of the internal political struggle, which often led to the forcible eviction of representatives of the defeated parties from the polises.

As a result of Greek colonization (called the second, or great Greek colonization in contrast to the first, which took place in the 13th century BC, when the Greeks settled the islands of the Aegean Sea and the western coast of Asia Minor), settlements appeared on territories that currently relate to Russia, Ukraine, Moldova, Romania, Bulgaria, Turkey and Georgia. In the Black Sea region, the Greeks lived in close surroundings of the Scythians, Sarmatians, Meots and other local peoples. The result of their proximity to these peoples was the mutual influence of cultures, within which the leading role belonged to Greek culture [7, p. 82].

The second channel of influence of ancient Greek charity on the social assistance of the peoples of the Black Sea region can be called indirect, since it was mediated by the culture of 
ancient Rome. Charity had pronounced Greek features in Ancient Rome, although it was limited only to them. Following the Greek patterns, the ancient Romans developed such forms as the organization of public meals, the distribution of money to the needy, as well as the construction of temples and bathhouses through private donations. At the same time, patronage, which is an aid to people of creative professions, was a phenomenon of Roman culture, which in ancient Greece had not yet developed [1, p. 87].

Social assistance had a class nature in antiquity and was aimed at supporting those who were considered a full member of society. However, at the beginning of the 1st millennium, marked by a sharp aggravation of the problems of ancient Roman society, a contradiction arose between the need for social assistance and the limited possibilities for its implementation. This contradiction was removed in Christianity, which offered its understanding of charity. According to this understanding, charity is the result of love that coincides with God in Christianity, and charity is a practical expression of benevolence. Therefore, the spread of Christianity, which began in $4^{\text {th }}$ century in Georgia, and then continued in other countries of the Black Sea region, contributed to the development of charitable activities in them.

\section{Лumepamypa}

1. Агапов Е.П. История социальной работы. М. Берлин, 2015. 353 с.

2. Античная драма. М., 1970. 768 с.

3. Боннар А. Греческая цивилизация. В 2 т. Т. 1. Ростов-на-Дону, 1994. 448 с.

4. Васильев Л.С. История Востока. В 2 т. Т. 1. М., 1994. 495 с.

5. Вейнмейстер А.В. Гостеприимство: к определению понятия. Теория и практика сервиса: экономика, социальная сфера, технологии. 2013. № 2 (16). С. 147-153.

6. Заякин C.В. Гостеприимство как социологическая проблема // Вестник Сургутского государственного педагогического университета. 2012. № 2. С. 127-132.

7. Иессен A.A. Греческая колонизация Северного Причерноморья: её предпосылки и особенности. Л., 1947.90 с.

8. Словарь античности. М., 1993. 704 с.

9. Фирсов М.В. История социальной работы. М., 2012. 400 с.

\section{References}

1. Agapov E.P. Istoriya sotsialnoy raboty. [History of social work]. 2015. Moscow. Berlin. 353 p. (In Russian).

2. Antichnaya drama. [Antique drama]. Moscow. 1970. 768 p. (In Russian).

3. Bonnar A. Grecheskaya tsivilizatsiya. [Greek civilization]. 1994. V. 1. Rostov-na-Donu. 448 p. (In Russian).

4. Vasiliev L.S. Istoriya Vostoka. [istory of the East]. Moscow. V. 1. 1994. 495 p. (In Russian).

5. Veynmeyster A.V. Gostepriimstvo: k opredeleniyu ponyatiya. Teoriya i praktika servisa: ekonomika, sotsialnaya sfera, tekhnologii. [Hospitality: to the definition of a concept. Theory and practice of service: economics, social sphere, technology]. 2013. No. 2(16). pp. 147-153 (In Russian).

6. Zayakin S.V. Gostepriimstvo kak sotsiologicheskaya problema. [Hospitality as a sociological problem. Bulletin of the Surgut State Pedagogical University]. Vestnik Surgutsko-go gosudarstvennogo pedagogicheskogo universiteta. 2012. No. 2. pp.127-132 (In Russian). 
7. Iyessen A.A. Grecheskaya kolonizatsiya Severnogo Prichernomorya: yeyo predposylki i osobennosti. [Greek colonization of the Northern Black Sea: its premises and features]. Leningrad. 1947. 90 p. (In Russian).

8. Slovar antichnosti. [Dictionary of antiquity]. 1993. Moscow. 704 p. (In Russian).

9. Firsov M.V. Istoriya sotsialnoy raboty. [History of social work]. Moscow. 2012. 400 p. (In Russian). 